Journal of Awareness

Cilt / Volume 5, Sayı / Issue 1, 2020, pp. 71-76

E - ISSN: 2149-6544

URL: https://www.ratingacademy.com.tr/ojs/index.php/joa

DOI: https://doi.org/10.26809/joa.5.006

Araştırma Makalesi / Research Article

\title{
PREVENTING AND COMBATING VIOLENCE AGAINST WOMEN: CASE OF TURKEY
}

\author{
Laura AGOLLI * \& Rriollza AGOLLI ** \\ * Oakland University Rochester, MICHIGAN \\ e-mail:lagolli@oakland.edu \\ ORCID ID: https://orcid.org/0000-0002-7429-9610 \\ * Msc., University "Fan S. Noli" \\ Korçë, ALBANIA e-mail: roza_ag@hotmail.com \\ ORCID ID: https://orcid.org/0000-0001-9152-0412
}

Geliş Tarihi: 17 Ocak 2020; Kabul Tarihi: 31 Ocak 2020

Received: 17 January 2020; Accepted: 31 January 2020

\section{ABSTRACT}

In a patriarchal society, violence against women is part of the expression of the legitimacy of male domination. This horror, as old as mankind itself, must end soon. Women should start to realize that they are far more valuable than men, more than just ideal mothers.

Women should understand that their values and powers go beyond the role of being good and obedient girls. Women's potentials should be used beyond superficial things. Today, women need to know how to achieve success and achieve meaningful goals and objectives rather than supporting other achievements. Strong women pursue personal accomplishments, promote themselves and contribute to society as a whole.

This article in particular is trying to raise awareness about the elimination of all forms of violence against violence in recent years to analyze and women against women as a widespread phenomenon in Turkey. Violence against a woman is the greatest dignity of humanity. At the same time, violence against women is obviously an indicator of helplessness. In order to completely eliminate this event, first of all, awareness should be raised against violence against women; Turkish society should be educated to support and protect women who are subjected to violence.

Key Words: woman, violence, awareness, patriarchal, society. 


\section{INTRODUCTION}

Violence against women is one of the most serious events facing society today. It is prevalent both physically and psychologically. However, most denunciations come from women and girls who are subjected to domestic violence. According to official statistics, only one in ten women report it to the police, and when patience is over, it comes a long time after the violence against them. This is justified in many cultures where men are still believed to have the right to control women's freedom and life. What are the most common causes? Economic crisis, alcohol and narcotic substances, lack of dual communication, betrayal and so on.

At first, many women are unaware that they are victims of abuse, but everything is stressed at work, alcohol, drugs, and so on. For this, they feel guilty of not being as good as one wants to find happiness, most of which comes from our traditional culture background, where women play a submissive role. Women believe that couples must stay together to overcome difficulties, regardless of circumstances. And most of them think that even if the father is the worst, the children need a father nearby. There are also women who do not have financial income, who cannot cope and prefer to endure. There are women who report the case, then they live in hidden danger both for themselves and for their children.

Violence against women is increasing in the world. This cruel dimension is a crime that has serious consequences that must be avoided at all costs. Statistics have stated that the reported numbers of violence are much lower than the actual number of violence.

\section{DEFINITION OF VIOLENCE AND ITS TYPES}

Violence is defined as "the intentional use of physical force or power, threatened or actual, against oneself, another person, or against a group or community, that either results in or has a high likelihood of resulting in injury, death, psychological harm, maldevelopment, or deprivation." 1

Arizona Coalition to end sexual and domestic violation ${ }^{2}$ makes a specific classification of types of domestic violence. So, first of all according to this website violence can be classified as physical abuse which includes direct or indirect aggressive behaviour or threat of physical abuse such as beating, hitting, physical assault, intimidation, threating with different weapons etc.

A second type of violence is control. Control is a perfect way for the maltreater to dominate the victim. Some examples of control may be wire-tapping, monitoring personal computers and other stuff by invading the privacy of a person; unexpected visits or calls which may become inconvenient and annoying for the victim.

The third type violence in this list is sexual abuse. Sexual abuse includes force and coercion, manipulation of the victim, sexual assault and offense, rape. Exhibiting extreme envy leading to false accusations of unfaithfulness and manipulating actio ns to restrict the victim's contact with the outside world is considered to be part of sexual abuse.

Furthermore, another type of violence is emotional abuse. That said to offend or criticize in order to weaken the self - confidence of the victim. It involves both public humiliations, real and implied rejection. At the same time it includes threatening with the intention of causing emotional or physical harm or injury; either directly or indirectly; denying or neglecting the needs of the victim, not allowing the victims to exercise their beliefs, isolating them from the community and convincing them that they are incompetent.

Verbal abuse is another type of violence. Any abusive language used to denigrate or intimidate the victim is considered to be verbal abuse. To continue with, one of the other types of violence is the fact of using the male privilege as cited in Arizona Coalition to end sexual 
and domestic violation. As long as our society continues to support the patriarchal ideology, men will continue to be dominant and violent. In almost every area of our daily lives, we can witness the male privilege. According to the Department of Justice approximately $80 \%$ of the offenders are men ${ }^{3}$. Male privilege points out the social norms and cultural expectations that contributed to the power and control structures at the heart of domestic violence. Boys are often supposed to solve violent and aggressive issues, and pursue power and control. Their acts are often excused.

As children these learned habits turn into men who always seek power in their relationships - and feel justified in using violence and aggression to obtain that influence. Abusers also blame women for their acts, finding reasons that this is happening because it is their fault (not theirs).

Moreover, economic abuse is also considered as one of the most critical violence type. Econimic violence is one way of manipulating economic resources in order to manipulate the victim. Victims are often forced to choose between violence and deprivation, or even homelessness. Economic violence is a common reason for the victims to stay in abusive relationships.

Stalking and stalking behaviors is the next type of violence. Enigmatic messages, watching someone from a distance, following someone, intimidating, not respecting someone's limitations, phone or social media harassing tactics etc.

\section{VIOLENCE AGAINST WOMEN IN TURKEY}

Turkey has one of the worst records in the world in terms of killings and violence against women, and experts say Turkish authorities fail to offer women adequate protection. National and international legislation provides full protection for women, but because of its understanding of the role of women, the Turkish Government is reluctant to fully implement such laws. Turkish state institutions do not publish regular data on the killings of women, but human rights NGOs collect data that is not very clear. Turkish women's rights organizations complain that violence against women has increased significantly in recent years. Even women experience violence on the open road, who is not properly dressed or dressed in a modern way.

In 2019 in Turkey 474 women were killed. This is the highest figure in the last 10 years. It is stated that 304 women were murdered in 2016, 353 in 2017 and 280 women were murdered in 2018. Existing data on violence against women have been compiled by media reports, but experts suspect the reality is much worse. Violence is usually not reported to legal authorities if it occurs within the family. If it is not within the family, it can be reported to the legal authorities, but then the government prefers to offer reconciliation rather than penalizing men. Women have second-class status in Turkey, and the government does not want to see them in prominent roles in society. The role of women is limited to being a mother, a wife, and a dependent on men. Historically, a certain level of violence against women, especially within the family, has been "acceptable" in Turkish society.

\section{THE CASE OF EMINE BULUT}

"I don't want to die!" Emine Bulut sighed as she waited for an ambulance after being attacked by her husband.

“Mom, don't die!" Her ten-year-old daughter cried with tears in her eyes.

Emine Bulut is just one of hundreds of victims in Turkey. At a time when Turkey has signed the Council of Europe's Istanbul Convention against Violence against Women, as 47 other countries. This ended up to be a disaster for Turkey and the community. 
Bulut became one of the latest victims of domestic violence in Turkey after her husband cut her throat in front of their daughter at a cafe in the Turkish province of Kirikkale on August 23 because she wanted to divorce him. All of this is seen in a video filmed on mobile that has shaken public opinion in Turkey. Emine Bulut, 38, died shortly after the stabbing attack at the hospital. After that thousands of people started the protests against violence against women. Not only public but also politicians,football clubs and celebrities condemned the violence.

Fedai Varai (43) was sentenced to life imprisonment. The court evaluated the action of the accused Fedai Varan within the scope of 'intentional manslaughter' and ruled for life imprisonment pursuant to Article 81 of the Turkish Penal Code.

\section{THE CASE OF GÜLEDA CANKEL}

Murdered by her boyfriend at a young age, Güleda Cankel was a student of Isparta University of Applied Sciences at the Department of Photography. Güleda was killed by her boyfriend Zafer P. It is knowm that Cankel wanted to break up with him. Pehlivan started by first squeezing her throat and then stabbing her in the chest. The other students who heard the sounds coming from Güleda Cankel's room found the young girl lying motionless. Police and health care teams were referred to the scene. Unfortunately Güleda Cankel could not survive and lost her life.

Guleda Cankel's last twitter post "breathing does not mean living," moved everyone to tears. Cankel lost her life three days after this post. There were several demonstrations all around the country. Turkish women stated that they did not feel safe anymore, tomorrow could be their turn to die.

Zafer Pehlivan, who surrendered to the police station 3 hours after the murder, reported that Güleda struggled for 17 hours and tried to escape 3 times during this period. Pehlivan was arrested by the court and was sent to the courthouse. Zafer Pehlivan will have his first Heavy Penal Court's hearing in 25 February 2020.

Social media was shaken up again with different posts under the hashtag \#GuledaCankel, each of them including important social messages. You can read some of the tweets below:

1.) Haluk Levent

El bebek büyüt

Yeme yedir.

Tek umudun kızının okuması mutlu olması olsun

Sonra bir katil gelsin onu bıçakla kessin!

Ana yüreği dayanır mı?

Kızlar!

Haluk abinizin tavsiyesi!

Sevgilinizde en ufak bir șiddet eğilimi gördüğünüzde uzaklașın

kaçın! Lanet okuyun sevgiye.\#guledacankel
Ruken

@Rkn_yyc

Sevmeyin bizi... \#GüledaCankel pic.twitter.com/nylp07UNDm

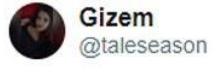

Bu kaçıncı kurban ettiğiniz can? Canını, kanını bekleyen bir ailenin evine düșürdüğünüz kaçıncı acı? Yeter artık durun! Sevgi bu kadar basit değil, olmamalı. Nurlar içinde uyu melek \#gueledacankel \#güledaiçinsusma \#susamam
Nurbanu Turan

@nurbanu_turan

İki gün önceki bu paylașımın altına 'mekanın cennet olsun' yazmıșlar.. Çünkü bir zamanlar ona 'aşkım' diyen biri tarafından önce boğulmak istendi sonra bıçaklanarak öldürüldü.. Susanın elinde kanı var 19 yașındaki bu kadının.. \#GüledaCankel 


\section{CONCLUSION}

The violence had and continues to have deep roots and all possible measures must be taken against it. Any act of any person that results in violating the physical, moral and psychological integrity of others especially women is an ugly and a reprehensible act. None of the women can remain silent and behave as if nothing happened, as the perpetrator will resume violence while the victim of this violence, or more precisely the victims will continue in the same situation. Criminal legislation has already been amended, both by law and by condemning domestic violence as a criminal offense with the latest amendments. Unfortunately, it took years and many casualties to go down this path, but this does not prevent the possibility of violence continuing. Thus the provision must be strictly enforced to bring about positive effects.

Murders or violence against women is not a country phenomenon or a cultural phenomenon. Violence against women is structurally a problem in our patriarchal societies despite international and national resolutions, conventions, action plans, and laws - despite the struggle of great feminists, efforts, and successes. Sometimes families become a dangerous place for many women. In a patriarchal society, violence against women is part of the expression of the legitimacy of male domination. This horror, as old as mankind itself, must end soon. Women should start to realize that they are far more valuable than men, more than just ideal mothers.

In order to completely eliminate this event, first of all, awareness should be raised against violence against women; Turkish society should be educated to support and protect women who are subjected to violence.

\footnotetext{
NOTES

${ }^{1}$ World report on violence and health (WRVH)

${ }^{2}$ https://www.acesdv.org/domestic-violence-graphics/types-of-abuse/

${ }^{3}$ https://www.bjs.gov/content/pub/pdf/fvs02.pdf
} 


\section{REFERENCES}

ALTINAY, A. G., \& ARAT, Y. (2009). Violence against women in Turkey: A nationwide survey.

BÜKEN, N. Ö., \& SAHINOGLU, S. (2006). Violence against women in Turkey and the role of women physicians. Nursing ethics, 13(2), 197-205.

DUROSE, M. R., HARLOW, C. W., LANGAN, P. A., MOTIVANS, M., RANTALA, R. R., \& SMITH, E. L. (2005). Bureau of Justice statistics, family violence statistics: Including statistics on strangers and acquaintances. Retrieved November, 16, 2007.

EMINE BULUT, adım adım ölüme böyle götürüldü. (2019, October 20). Retrieved from http://www.hurriyet.com.tr/gundem/emine-bulut-adim-adim-olume-boyle-goturuldu41354515

HEISE, L., ELLSBERG, M., \& GOTTEMOELLER, M. (1999). Ending violence against women. Population reports, 27(4), 1-1.

İKİNCİ, S. S. Toplumun Kanayan Yarası: Kadına Yönelik Aile İçi Şiddet Kavramı ve Yansımaları. Ankara Sağllk Hizmetleri Dergisi, 13(2), 21-28.

JOHNSON, M. P. (1995). Patriarchal terrorism and common couple violence: Two forms of violence against women. Journal of Marriage and the Family, 283-294.

Justice, Office of Justice Programs, National Institute of Justice.

KOCACIK, F., KUTLAR, A., \& ERSELCAN, F. (2007). Domestic violence against women: A field study in Turkey. The Social Science Journal, 44(4), 698-720.

National Research Council. (1996). Understanding violence against women. National Academies Press.

'Our demand as women is not to be killed'. (2019, August 23). Retrieved from https://www.bbc.com/news/world-europe-49446389

SEMENZA, D. C. (2019). World Report on Violence and Health. The Encyclopedia of Women and Crime, 1-3. doi: 10.1002/9781118929803.ewac0544

TJADEN, P. G. (2000). Full report of the prevalence, incidence, and consequences of violence against women: Findings from the National Violence Against Women Survey. US Department of State.

Türkiye'yi yasa boğan Güleda Cankel kimdir? Güleda Cankel'in katili Zafer'in ifadesi. (2019, November 20). Retrieved from http://www.hurriyet.com.tr/gundem/turkiyeyi-yasabogan-guleda-cankel-olayi-nedir-guleda-cankel-kimdir-41377754

TYPES of Domestic Violence. (2014, June 25). Retrieved from https://www.acesdv.org/domestic-violence-graphics/types-of-abuse/

19 Yaşındaydı: Üniversite Öğrencisi Güleda Cankel 'Sevgilisi' Tarafından Bıçaklanarak Öldürüldü. (2019, November 19). Retrieved from Onedio.com. (2019, November 19). 19 Ya?'ndayd?: Üniversite Ö'rencisi Güleda Cankel 'Sevgilisi' Taraf'ndan B?çaklanarak Öldürüldü. Retrieved from https://onedio.com/haber/19-yasindaydi-universiteliogrencisi-guleda-cankel-sevgilisi-tarafindan-bicaklanarak-olduruldu-889899 